\title{
Spontaneous Intranasal Meningocele: A Case Report Spontan İntranazal Meningosel: Bir Olgu Sunumu
}

\author{
${ }^{1}$ İdris ÇILDIR \\ ${ }^{1}$ Karaman State Hospital Ear Nose Throat, Karaman, TURKEY \\ İdris Çıldır: https://orcid.org/0000-0003-3615-8734
}

\begin{abstract}
$\ddot{O Z Z}$
Burun içi meningosel, kribriform plakadaki defekte bağlı olarak meninkslerin burun boşluğuna fitıklaşması sonucunda ortaya çıkan patolojidir. Bunlar, sıklıkla pediatrik popülasyonda kafatası tabanındaki doğuştan bir defekt nedeniyle bulunur. Burun içi meningosel, erişkinlerde çok nadirdir ve genellikle travma sonucu ortaya çıkar. En belirgin semptom burun akıntısı ve tıkanıklığıdır. Poliplere benzediğinden teşhis edilmeleri zordur. Teşhis edilmediği takdirde ciddi komplikasyonlara yol açarlar. Tedavisi cerrahi olup günümüzde kullanılan cerrahi yöntem intranazal yolla kafa tabanı defektinin kapatılmasıdır. Elli dokuz yaşındaki bir kadın hasta da, meningosele bağlı dural defekt,intranazal yolla kapatıldı. Postoperatif 10 aylık takiplerinde herhangi bir beyin omurilik sıvısı sızıntısı ya da başka bir komplikasyon bildirilmedi. Bu vaka literatür eşliğinde sunuldu.

Anahtar Kelimeler: Etmoid kemik, meningosel,nazal polip
\end{abstract}

\section{ABSTRACT}

Intranasal meningocele is a pathology that occurs as a result of herniation of the meninges in the nasal cavity usually due to defects of the cribriform plate. They are frequently found in the pediatric population as a result of congenital defects at the base of the skull. Intranasal meningoceles are very rare in adults and usually occur as a consequence of trauma. The most obvious symptoms are nasal discharge and obstruction, making diagnosis difficult as they resemble polyps. Intranasal meningoceles may cause serious complications unless promptly diagnosed and treated via surgery. The most commonly used surgical procedure today is the closure of the skull base defect through intranasal route. In our case, the dural defect of our 59-year-old female patient with intranasal meningocele was repaired with this technique. Postoperative 10 months follow-up showed neither cerebrospinal fluid leakage nor other complications. We present this case with a summary of relevant literature.

Keywords: Ethmoid bone, meningocele, nasal polyp

\section{Sorumlu Yazar / Corresponding Author:}

İdris Çıldır

Karaman State Hospital, Üniversite Mh., 1984. Sok.

Yayın Bilgisi / Article Info:

Gönderi Tarihi/ Received:07/02/2019

Kabul Tarihi/ Accepted: 21/06/2019

No:1, 70200 Merkez/Karaman

Tel: +90 (505) 7898974 +90 (338) 2263002

Online Yayın Tarihi/ Published: 31/03/2020

E-Mail:idriscildir@hotmail.com

Atıf/ Cited: Çıldır I. Spontaneous Intranasal Meningocele: A Case Report. Online Türk Sağlık Bilimleri Dergisi 2020;5(1):193-198. doi: 10.26453 otjhs.522896

\section{INTRODUCTION}

Simply put, a meningocele is a sac filled with cerebrospinal fluid (CSF) that occurs as a result of meninx protrusions due to various reasons. If neural tissue protrudes into the sac, it is called an encephalocele, if both the neural tissue and the meninges and involved, it is called a meningoencephalocele. These abnormalities can develop anywhere along with the head and spine. There are congenital and acquired forms; congenital cases are frequently seen in children, whereas acquired ones are seen in adults and are usually a result of trauma.

The causes of congenital meningoceles are not precisely known; however, some theories have been pro- posed. One of the most popular theories is the suggestion that defects of the neural tube during the $3^{\text {rd }}$ and $4^{\text {th }}$ weeks of embryogenic development are the fundamental cause of meningoceles. Another popular theory attributes the closure defect due to variances in head bone development. ${ }^{1}$

The incidence of meningoceles vary greatly, they are reported to bemost common in the Asian region with a frequency of 1/5000 live births. This frequency is between 1/35000-40000 in America and Europe. ${ }^{2}$ Acquired meningoceles are more common in adults and women, with the majority of cases attributed to trauma. Spontaneous meningocele in adults is quite rare. $^{3}$ 
The history of the patient is crucial to the diagnosis. A history of trauma and symptoms such as continuous nasal discharge, nasal obstruction and headache should be questioned. In physical examination, polypoid masses, especially in the unilateral nasal cavity, should be carefully examined and biopsy should not be taken unless it is examined radiologically. Otherwise, it may result in meningitis and death of the patient. Radiologically, CT (Computed Tomography) and MRI (Magnetic Resonance Imaging) will give us important clues about the lesion. Cranial defects detected during or before the operation are successfully repaired by transnasal endoscopic method.

\section{CASE REPORT}

A 59-year-old female patient was admitted to the outpatient clinic with complaints of discharge and obstruction in her right nose which continued for 5 years. She had no history of trauma, operation, or allergic rhinitis. The patient, who had frequently received treatment for allergic rhinitis and nasal polyps, had a polypoid-like tumoral mass filling the right nasal cavity on physical examination. Firstly, a paranasal sinus CT was ordered in accordance with a diagnosis of nasal polyp (Figure 1). Based on the radiology report of the tomography, the patient was scheduled for a nasal polyp operation. After obtaining informed consent for the surgery, the patient was taken into the operation room and surgery was begun. During the operation, it was observed that the polypoid-like tissue had a fluid-filled sac and was extending to the base of the skull. A repeat analysis of CT revealed a defect on the right ethmoid roof. It was found that the sac that caused the 4-5 mm defect on the ethmoid roof was actually a meningocele (Figure 2).The patient was considered spontaneous meningocele due to the patient was 59-year-old woman who has no history of trauma and surgical intervention. The other reasons were obesity and hypertensive risk factors that may cause increased intracranial pressure, presence of complaints for the last 5 years and meningeal pouch during surgery.

The surgery was then continued in accordance with meningocele removal and the sac was followed to the base of the skull. Residual tissues on the skull base were cauterized. The defect was closed with the muscle and fascia graft taken from the back of the right thigh. One more muscle and fascia layer was placed. The closures was then finalized with the placement of the sphenopalatine artery-based nasoseptal mucoperiosteal flap.To increase resistance to
CSF pressure and prevent graft slipping, a Nelaton urinary catheter was inflated inside the nose. A Doyle silicone nasal splint and spongastan were placed and the operation was completed. The patient was hospitalized for 3 days. To reduce CSF pressure and prevent the risk of infection, acetazolamide treatment and antibiotics were initiated. At the postoperative 1st week, the Nelaton catheter and tampons inside the nose were removed. No CSF leakage was observed during periodic follow-ups. Pathological examination of the specimen was reported as meningocele.

\section{DISCUSSION AND CONCLUSION}

Intranasal meningocele is a pathology that is frequently confused with nasal polyps and seen rarely in adulthood. $20 \%$ of all meningoceles are seen in the cranium; $15 \%$ of them are localized inside the nose. Nasal localized meningoceles are divided into two groups: sincipital (60\%) and basal (40\%).

Sincipital meningoceles are divided into 3 subgroups: nasofrontal, nasoethmoidal, nasoorbital. These are most often soft masses that are located at the glabella. ${ }^{4}$ Basal meningoceles are divided into 4 subgroups: transetmoidal, sphenoethmoidal, transsphenoidal and transorbital. ${ }^{5}$

The incidence is reported to be between 0.8-4 in 10,000 births and the majority of studies have found no gender dominance. ${ }^{1,3}$ Most of the cases of meningocele in the nasal cavity develop due to a defect in the anterior skull base. These defects are inadequate fusion in the skull bones which may be a result of congenital neural tube defects. In adults, it often occurs due to traumatic or iatrogenic causes and rarely occurs spontaneously.

In spontaneous cases, the meningocele progresses due to an increase in CSF and hydrostatic pressure, as a result of increased intracranial pressure (ICP). Meningocele develops as a result of herniation of the meninges from the anatomical weak points on the skull base (optic nerve sheath, cribriform plate, bone processes on the anterior and posterior skull base). With further increase in pressure, meningoceles may cause sac ruptures and CSF leakage. Gender and obesity play an important role in the idiopathic intracranial pressure increase. The majority of these cases are seen women. In our case, the patient was an obese and hypertensive woman, which conforms to the literature.

Patients may exhibit different findings and symptoms such as nasal obstruction, CSF rhinorrhea and recurrent meningitis. Moreover, some of the patients 
can be followed for years with misdiagnoses of allergic rhinitis and nasal polyps. It is easier to diagnose in infancy owing to the fact that they are often accompanied by other congenital anomalies. MRI can complement the anatomical information provided by $\mathrm{CT}$ in terms of the size and location of the stalk of the lesion and the presence of vessels within the sac. MR cisternography does not require the intrathecal administration of a contrast agent and may become the imaging modality.MR cisternography is noninvasive and has a reported sensitivity, specificity, and accuracy of $87 \%, 57 \%$, and $96 \%$, respectively, when combined with coronal $\mathrm{CT} .{ }^{6}$ The case presented in this study received treatment of allergic rhinitis and nasal polyps because of the nasal discharge and nasal obstruction for many years. The preoperative tomography was interpreted as nasal polyps by a radiologist and it was found that the pathology was meningocele during the operation. Therefore, although the radiology report is important, it is very crucial to examine the preoperative radiological sections carefully before surgery.

The Valsalva maneuver is utilized to separate meningoceles from gliomas in the clinical setting. With this maneuver, meningoceles increase in size and get larger and the transillumination test is positive (Furstenberg's sign), while gliomas do not demonstrate these characteristics.

Treatment of meningocele is surgery. Surgical repair of CSF leakage using a frontal craniotomy approach was first described by Dandy in 1926. This was followed by extracranial and transnasal approaches in the $1950 \mathrm{~s}^{7}$ The extracranial technique was claimed to provide a better visual field for the surgeon, to allow the use of large flaps and to reduce the risk of infection. ${ }^{5}$ However, as a result of the studies, it was found that the success rate was only $70 \%$ and the rate of recurrence, mortality, and morbidity was high with this technique. ${ }^{8}$ In 1981, Wigand repaired CSF leakagevia endoscopic sinus surgery for the first time. This technique was then further developed, allowing it to be used in the endonasal repair of defects at the skull base, and was also presented as a safe and alternative technique by significantly reducing postoperative mortality and morbidity. ${ }^{9}$ In a prospective study a success rate of $93.8 \%$ was reported and the authors concluded that endoscopic repair of non-traumatic anterior encephalocele was successful. ${ }^{10}$ In our case, we successfully closed the gap in the anterior skull base through the endoscopic endonasal method.

To conclude, a meningocele diagnosis should be considered in adult patients, especially in those with unilateral nasal polyp and/or prolonged unilateral nasal discharge. Thin section multidetector CT should be performed and a good clinical knowledge is given to the radiologist and images should be evaluated with the radiologist if possible. MR and / or MR cisternography examinations should be added in patients with non-regressive pathologies, considering the possibility of non-polypoid pathology. The clinician should not neglect to re-evaluate radiological images before the operation.

Ethics Committee Approval: Ethics committee approval is not required for this study. The patient's consent was obtained.

Conflict of Interest: No conflict of interest was declared by the author.

Author Contributions: Concept - I.C.; Supervision I.C.; Materials - I.C.; Data Collection and/or Processing - I.C.; Analysis and/ or Interpretation - I.C.; Writing - I.C.

Peer-review: Externally peer-reviewed.

\section{REFERENCES}

1. David DJ. Cephaloceles classification, pathology, and management-a review. J Craniofac Surg. 1993;4(4):192-202.

2. Castaño-Duque $\mathrm{CH}$, Monfort L, Muntané A, de Miquel MA, Pons-Irazaz. Trans-ethmoid meningocele diagnosed in adults abal LC, López -Moreno JL. Rev Neurol. 1997;25(138):230-233.

3. Nager GT. Cephaloceles. Laryngoscope. 1987;7 (1):77-84.

4. Kollias SS, Ball WS, Congenital Malformation of Brain Chapter 5. In Pediatric Neuroradiology Ed. Ball WS. Lippincott; 1997:2327-2346.

5. Malik R, Pandya VK, Parteki S. Fronto ethmoidal meningocele. Neuroradiology. 2004;14(4):379-381.

6. Shetty P, Shroff MM, Sahani DV. Evaluation of high-resolution $\mathrm{CT}$ and MR cisternography in the diagnosis of cerebrospinal fluid fistula. Am J Neuroradiol. 1998;19633-639

7. İsmi O, Özcan C, Vayısoğlu Y, Koray K, Kuyucu N. Endoscopik Nazal meningocele and CSF Leak Repair using inferior Turbinate Greft. Turkish J Rhinology. 2015;4(1):34-8.

8. Martín C. Martínez CG, Serramito GR, Espinosa 
RF. Surgical challenge: endoscopic repair of cerebrospinal fluid leak. BMC Res Notes. 2012;5:459.

9. RandolphG. Comprehensive Techniques in CSF Leak Repair and Skull Base Reconstruction.Adv Otorhinolaryngol. 2013;(74):33-41.

10. Nyquist GG, Anand VK, Mehra S, Kacker A, Schwartz TH. Endoscopic endonasal repair of anterior skull base non-traumatic cerebrospinal fluid leaks, meningoceles, and encephaloceles. J Neurosurg. 2010;113(5):961-6 


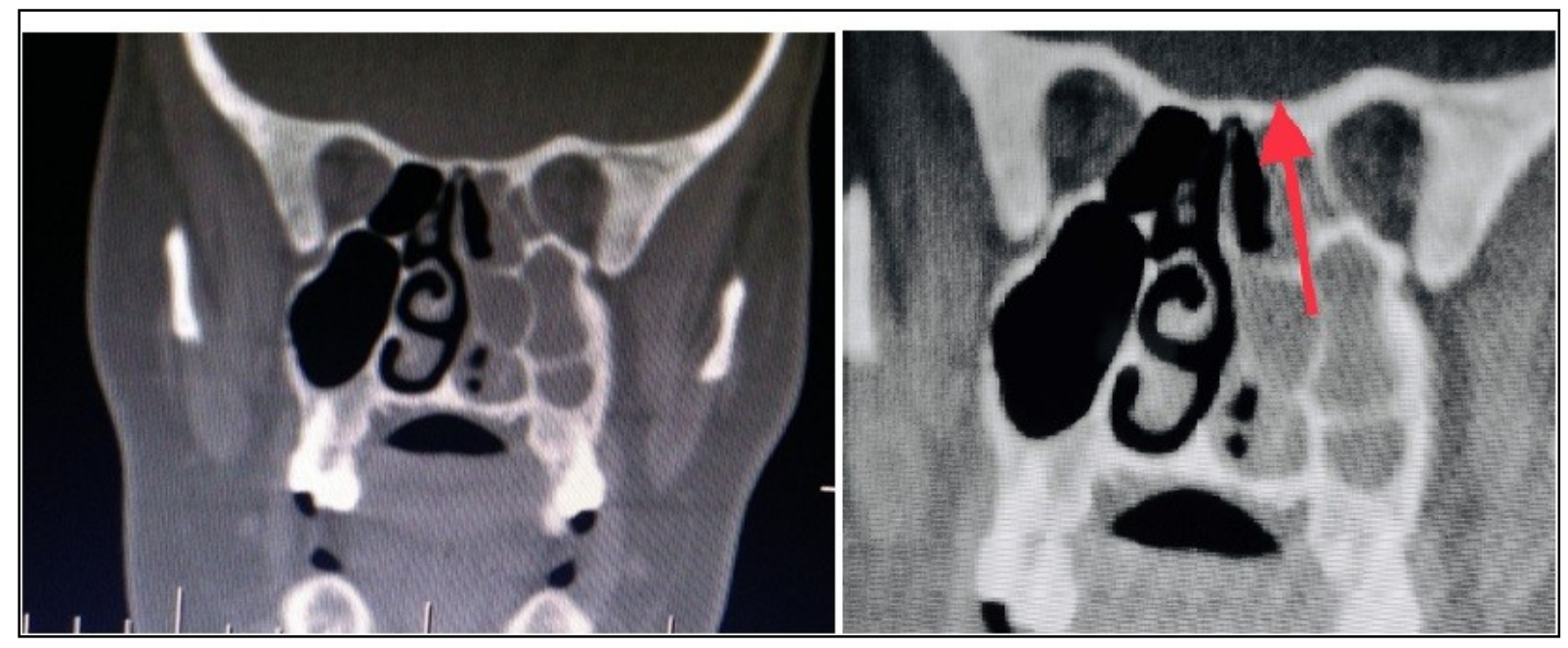

Figure 1. Polypoid mass filling the right intranasal cavity. 


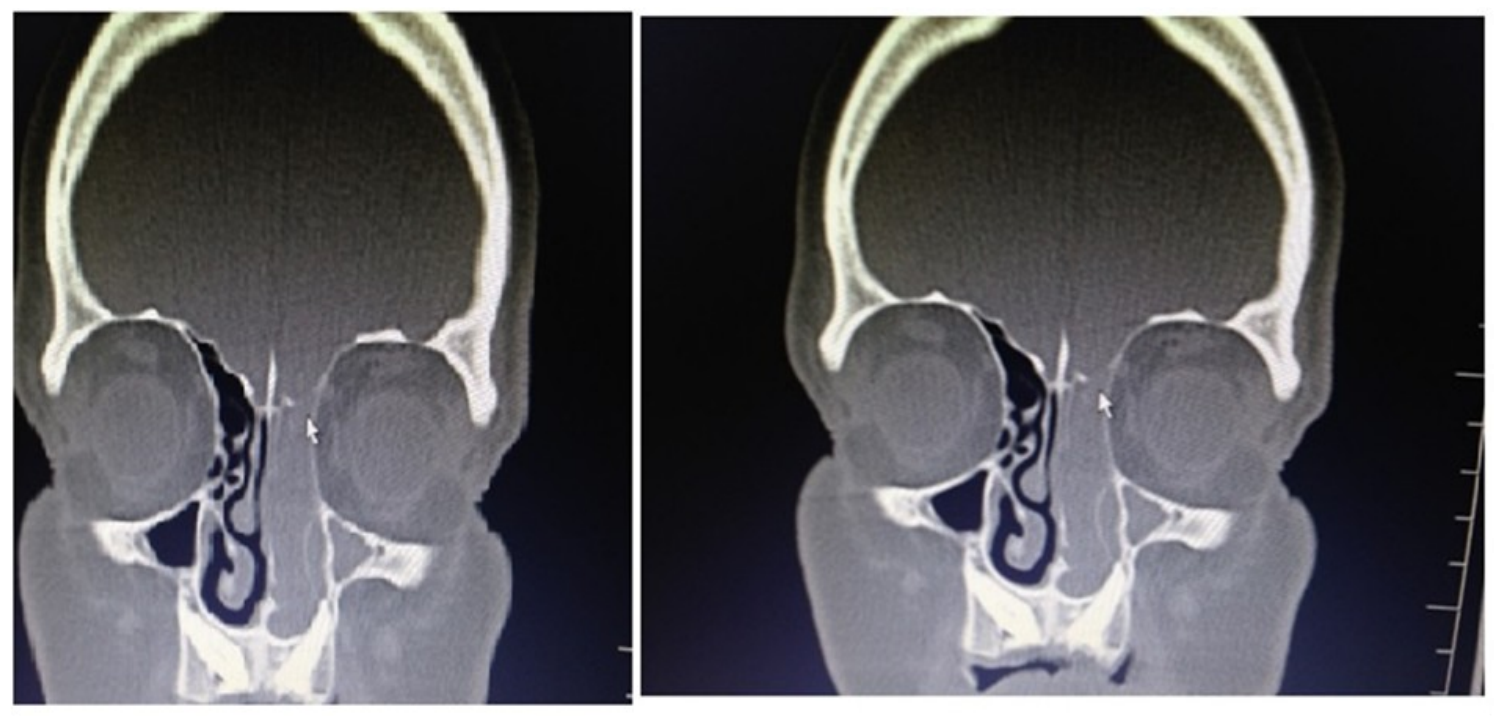

Figure 2. Defect in the right ethmoid roof. (white arrow). 